\title{
Colombians in the United States: A Study of Their Well-Being
}

\section{Cándida Madrigal}

\begin{abstract}
This study examined the extent to which four factors-acculturation, ethnic identity, self-esteem, and resilience-can explain the well-being of Colombian immigrants in the United States across three waves of immigration (wave 1, from 19451964; wave 2, from 1965-1989; and wave 3, from 1990-2008). The results indicate that of the four factors, self-esteem most correlated with and was a predictor of well-being. Participants exhibited high levels of well-being as their level of self-esteem increased. Ethnic identity negatively predicted well-being, especially for men who entered during wave 3; as the extent of their ethnic identity increased, their well-being decreased. Correspondingly, Colombians who entered as political refugees reported a lower level of well-being. This research was groundbreaking in assessing factors contributing to the well-being of Colombian immigrants and assisting in the search for appropriate scales to study this population. Although its results have to be considered with caution, the study opens doors to future research, policies, and programs regarding the mental health assessment and treatment of Colombians in the United States.
\end{abstract}

Keywords: Colombians, immigrants, well-being, ethnic identity, self-esteem

People leave their country of origin for numerous reasons such as political refuge, economic advancement, religion, adventure, educational opportunities, or just to take an extended vacation (Segal, 2002; Segal, Elliott, \& Mayadas, 2010). The reason for migration affects the immigrant's intent to stay permanently in another place, and may have both positive and negative consequences to the person's well-being, as the resettlement experience affects psychosocial adjustment. Many factors influence immigrant health and psychological well-being, including some specific demographic and migration characteristics, coping resources, and perceptions of life circumstances (Christopher \& Aroian, 1998). Moving to a new country may contribute to improvement in the quality of life, which in turn can influence a person's psychosocial adjustment, or it can have adverse consequences, creating new unresolved psychosocial consequences for the well-being of an immigrant.

The United States of America is comprised of diverse and heterogeneous ethnic and racial groups, including those called minorities and the dominant European American majority group (Zhou \& Bankston, 1998). Multiculturalists view immigrants as actively participating in the shaping of their lives and consider them integral segments of American society. The well-being of immigrants has been widely documented on the basis of existing theory and research. Early research sought to better understand the relationship between conditions in society, in the family, and how healthy individuals adjust to their environments. Several models have been developed, recommended, and tested to further understand psychological and health-related outcomes for diverse immigrant groups (Abouguendia, 2001; Campbell, 1981; Christopher \& Aroian, 1998; Dupuy, 1977; Kuo-Jackson, 2000; Mahoney, 2004; Phinney, 2003).

Cándida Madrigal, Ph.D. MSW, is an Assistant Professor in the Department of Social Work at San Francisco State University.

Copyright (C) 2013 Advances in Social Work Vol. 14 No. 1 (Spring 2013), 26-48 
Colombians have been arriving in the United States since the 1930s. Initially they came to advance their education or economic situations, and in some cases, to search for adventure. Since the late 1990s, they have arrived primarily to escape violent internal armed conflict. The political and economic turbulence in Colombia has involved an internal/external political crisis with an alarming connection among drug traffickers, the guerilla groups, and the paramilitary groups, who work together in attempting to control either the land or the drug trade (Collier \& Gamarra, 2001; Reimers, 2005; Sanchez, 2003; Shifter, 1999; U.S. Department of Homeland Security, 2012). The increasing violence, threats of extortion, kidnapping, murder, and an "undeclared civil war" have caused a large number of Colombians to leave their country in hopes of finding a safer home.

Although Colombians represent one of the largest groups of immigrants from South America in the United States, much of the research available is based on groups with ethnic labels such as "Hispanics" or "Latinos." Most of these studies are conducted with Cuban, Cuban American, Puerto Rican, mixed Mexican, or Mexican American populations; Central/South American populations combined; or under an "Other Hispanic” category (InfoPlease, 2011; Longres \& Patterson, 2000; Rumbaut, 1996). Other studies have been conducted with unspecified groups of Spanish-speaking or Spanish-surnamed populations. This research approach is misleading because there are very important ethnic and cultural differences among groups, whether Latin American or Caribbean (Longres \& Patterson, 2000; Rumbaut, 1996).

This article discusses acculturation, ethnic identity, resilience, and self-esteem as a framework to study the well-being of Colombian immigrants residing in the United States. It provides a background history of their reasons for leaving their country and their immigration patterns. It explains the results of the study, the limitations, as well as implications for social work practice, policy, education, and research.

\section{Importance of the Study}

It is of prime importance to study the well-being of Latinos in the United States because their presence is significant. As of July 1, 2011, 52 million people in the United States were Latinos, representing $16.7 \%$ of the total population and making them the largest ethnic or racial minority in the country. By the year 2050, it is estimated that there will be 132.8 million Latinos in the United States, comprising $30 \%$ of the total population (InfoPlease, 2011). The connection between Latino/Hispanics and the United States extends to all areas, political, social, cultural, and economic.

It is also important to study the nationality groups individually since their immigrant trajectory may be different. This study focuses on Colombian immigrants. The greatest number of immigrants who have entered the United States from South America are Colombians, accounting for $23.3 \%$ of the overall South American-born population in the country (Acosta \& De la Cruz, 2011). However, there are limited available historical references concerning Colombian immigrants to the United States. More specifically, there is little information regarding their immigrant experience and the factors that affect their well-being in the host country. In 1999 Guarnizo, Sanchez, and Roach stated that, 
"While Colombians constitute an important wave of immigrants; nonetheless they are an understudied ethnic group" (p. 5), and today, in 2013, they continue to be understudied.

Colombians play a very important role because they continue to arrive to the United States and are integral to this country. Therefore, it is appropriate to explore the immigration waves of Colombians to the United States and understand the factors that contribute to their well-being. Furthermore, because social services and financial resources for immigrants have been limited, it is imperative that the social programs developed to assist immigrants in the United States, specifically Colombians, be based on a concrete understanding of the factors that contribute to their overall well-being in the United States.

\section{Literature Review}

\section{Immigration Patterns as Waves}

Records show that Colombians began arriving in the United States in the 1930s when there were 1,233 Colombians residing in the country; by the 1940s this number had reached 3,858 (United States Immigration and Naturalization Service, [USINS], 1970). Although there is a consensus in the available literature about the immigration patterns of Colombians to the United States unfolding in three waves, there is a discrepancy regarding the exact periods and limited information about the reasons that led to these patterns. Collier and Gamarra (2001) list the time periods as 1950 to the end of the 1970s, late 1970s to the mid 1990s, and the mid 1990s to the present.

However, Sanchez (2003) suggests the three periods of immigration to the United States were from 1945-1965; 1966-1990; and 1991-2000. He links the time frames to the internal conditions in Colombia, the United States' immigration policies, and the overall receiving context. Nevertheless, there are indications that wave 3 extended to the year 2008, given the sociopolitical situation both in Colombia and the United States. For a detailed description of the characteristics of the migration of Colombians to the United States by wave, from 1945 to 2008, see table 1. The years between 2008 and 2013 have been impacted by different social and political situations both in the United States and Colombia, including newly elected Presidents, and the efforts of President Juan Manuel Santos Calderón (elected in 2010) to reach peace agreements with the diverse armed groups in Colombia. Specific information regarding the characteristics of this new wave of Colombian immigration to the USA, although of great interest, is beyond the scope of this paper. 
Table 1 Characteristics of Colombian Migration to the United States by Waves

\begin{tabular}{|c|c|c|}
\hline WAVE & $\begin{array}{l}\text { Reasons for Leaving Colombia. } \\
\text { Pushed Factors: Conditions in Colombia }\end{array}$ & $\begin{array}{l}\text { Reasons for Migrating to USA. } \\
\text { Pulled Factors: Cultural attraction, } \\
\text { United States' immigration policies and } \\
\text { the overall receiving context }\end{array}$ \\
\hline $\begin{array}{l}\text { Wave } 1 \\
\text { 1945-1965 }\end{array}$ & $\begin{array}{l}\text {-Political turmoil in the country. } \\
\text {-1949. Assassination of Jorge Eliecer Gaitan, a } \\
\text { young political leader from the Liberal Party. } \\
\text {-Period known as La Violencia, (The } \\
\text { Violence), a civil war between the two } \\
\text { political parties in the country that killed more } \\
\text { than 200,000 Colombians }{ }^{1} \text { and destroyed } \\
\text { most of the agriculture in the country. } \\
\text {-Thousands of Colombians lost their land and } \\
\text { were forced to move to major cities. } \\
\text {-Searching for a solution to this internal crisis, } \\
\text { the elite political parties agreed on a pact that } \\
\text { created an "exclusionary political system," } 4 \\
\text { which, in addition to the political violence in } \\
\text { the country, the absence of economic } \\
\text { opportunities, and the cultural magnetism to } \\
\text { the United States, including financial } \\
\text { prospects, precipitated the exit of Colombians } \\
\text { from their country. } \\
\text {-By the } 1950 \text { s, there were } 18,048 \text { Colombian } \\
\text { nationals in the United States, and by } 1960 \\
\text { there were } 72,028 \text { permanent Colombian } \\
\text { residents. }\end{array}$ & $\begin{array}{l}\text {-Cultural magnetism to the United States, } \\
\text { including financial prospects. } \\
\text { - The primary factors that have attracted } \\
\text { Colombians to the United States } \\
\text { throughout their migratory patterns include } \\
\text { "the promise of jobs, peace, and stability. . } \\
\text {.these immigrants have sought to escape } \\
\text { the political violence, while searching for } \\
\text { economic opportunities" (Collier \& } \\
\text { Gamarra, 2001, p. 4). } \\
\text { - While the unstable economic and } \\
\text { political situation in the home country } \\
\text { were the primary push factors, Collier and } \\
\text { Gamarra (2001) contend that during this } \\
\text { period individuals from the middle, upper- } \\
\text { middle, and upper classes-primarily from } \\
\text { the large cities of Bogotá, Medellin, and } \\
\text { Cali-not only came in search of better } \\
\text { economic prospects, but also to look for } \\
\text { adventure. They state that “Colombians } \\
\text { are risk-takers, have a sense of adventure } \\
\text { and a history of migrating” (Collier \& } \\
\text { Gamarra, 2001, p. 3). }\end{array}$ \\
\hline $\begin{array}{l}\text { Wave } 2 \\
1966-1990\end{array}$ & $\begin{array}{l}\text {-The situation in Colombia got worse, both } \\
\text { economically as well as politically } \\
\text {-By 1964, and through the } 1970 \text { s, a large } \\
\text { percentage of the country's revenue was } \\
\text { controlled by a small number of families and } \\
\text { the inequality and inability to earn income } \\
\text { diminished the capacity to buy goods. }^{6} \\
\text {-Levels of internal political violence in the } \\
\text { countryside had increased. } \\
\text {-The weak political and economic conditions } \\
\text { of the country were additionally complicated } \\
\text { by the reality that Colombia was rising as a } \\
\text { major manufacturer, trafficker, and provider of } \\
\text { marijuana and cocaine }{ }^{7} \text { as well as heroin to } \\
\text { many parts of the world. } \\
\text {-During this period, Colombia surfaced as the } \\
\text { most important actor in the dispensation and } \\
\text { circulation of cocaine's succession of global } \\
\text { commodity. } \\
\text {-Migration of Colombians to the United States } \\
\text { rose significantly during this period. } \\
\text {-By the end of the } 1980 \text { s, there were } 122,849 \\
\text { Colombians residing in the United States. }\end{array}$ & $\begin{array}{l}\text {-Amendments to the immigration laws in } \\
\text { the United States. } \\
\text {-The U.S. Immigration and Naturalization } \\
\text { Act's } 1965 \text { amendments, which allowed } \\
\text { every country a quota of } 20,000 \text { new } \\
\text { immigrants per year (Collier \& Gamarra, } \\
\text { 2001, Hing, 2004) and also had a } \\
\text { provision for family reunification (Hing, } \\
\text { 2004) that made it possible for many } \\
\text { relatives to immigrate, thereby, creating a } \\
\text { great influx of Colombians and other Latin } \\
\text { Americans during the late 1960s and } \\
\text { 1980s (Sanchez, 2003). } \\
\text { Many Colombians who came to the United } \\
\text { States during these years were affected by } \\
\text { the stereotyping and stigmatizing of the } \\
\text { drug epidemic. Colombians were often } \\
\text { referred to as drug traffickers (Collier \& } \\
\text { Gamarra, 2001; Jones-Correa, 1998; } \\
\text { Sanchez, 2003; Tazi, 2004). This was a } \\
\text { particular language used to support the } \\
\text { ideas held about Colombians that created } \\
\text { biased judgments towards all Colombians } \\
\text { since they were perceived according to this } \\
\text { image of drug traffickers. }\end{array}$ \\
\hline
\end{tabular}


Table 1 (cont.)

\begin{tabular}{|c|c|c|}
\hline WAVE & $\begin{array}{l}\text { Reasons for Leaving Colombia. } \\
\text { Pushed Factors: Conditions in Colombia }\end{array}$ & $\begin{array}{l}\text { Reasons for Migrating to USA. } \\
\text { Pulled Factors: Cultural attraction, } \\
\text { United States' immigration policies and } \\
\text { the overall receiving context }\end{array}$ \\
\hline $\begin{array}{l}\text { Wave } 3 \\
1991-2008\end{array}$ & 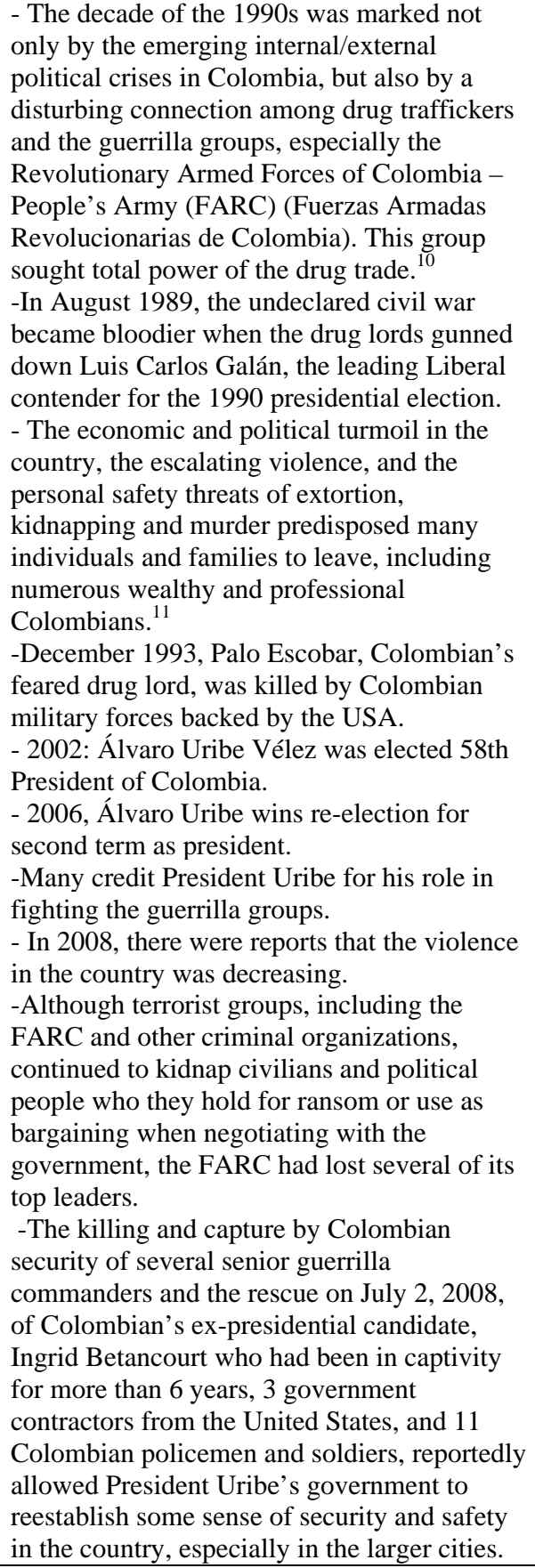 & $\begin{array}{l}\text {-The situation in Colombia during these } \\
\text { years produced considerable apprehension } \\
\text { for the U.S. government and its military. } \\
\text {-As a result, Colombia and the U.S. } \\
\text { administration established "Plan } \\
\text { Colombia” to support the Colombian } \\
\text { government in eradicating the drugs, } \\
\text { combating the rebel groups and } \\
\text { strengthening the military, with millions of } \\
\text { dollars (Collier \& Gamarra, 2001, } \\
\text { Reimers, 2005; Sanchez, 2003; Shifter, } \\
\text { 1999). } \\
\text { - By the 1990s, many middle, upper- } \\
\text { middle, and upper-class individuals and } \\
\text { trained professionals entered the United } \\
\text { States on tourist visas but stayed without } \\
\text { legal documents after their visas expired } \\
\text { (Collier \& Gamarra, 2001; Reimers, } \\
\text { 2005). } \\
\text {-2003. The Department of State refused to } \\
\text { grant TPS to Colombians, stating that the } \\
\text { home conditions had improved and that a } \\
\text { significant number of Colombians had } \\
\text { already been granted asylum (Reimers, } \\
\text { 2005). } \\
\text {-If undocumented, Colombians who } \\
\text { entered during this wave have found } \\
\text { themselves experiencing concerns and } \\
\text { frustrations at their inability to obtain legal } \\
\text { status, regardless of their educational and } \\
\text { socioeconomic background. They find it } \\
\text { difficult to understand the U.S. system and } \\
\text { accept that they cannot obtain licenses and } \\
\text { permits to work in their line of business or } \\
\text { profession. For example, they are not used } \\
\text { to “competing for jobs based upon their } \\
\text { qualifications; instead, they are used to } \\
\text { gaining employment through close } \\
\text { networks of family and friends" (Collier \& } \\
\text { Gamarra, 2001, p. 9). } \\
\text {-2008 was an election year in the United } \\
\text { States, therefore the "Department of } \\
\text { Homeland Security's widening immigrant } \\
\text { round-up," and President Bush's anti- } \\
\text { immigration laws and regime were left to } \\
\text { be dealt with by the next administration } \\
\text { (Barry, 2008, p. } 1 \text { ). }\end{array}$ \\
\hline
\end{tabular}


Table 1 (cont.)

\begin{tabular}{|c|c|c|}
\hline WAVE & $\begin{array}{l}\text { Reasons for Leaving Colombia. } \\
\text { Pushed Factors: Conditions in Colombia }\end{array}$ & $\begin{array}{l}\text { Reasons for Migrating to USA. } \\
\text { Pulled Factors: Cultural attraction, } \\
\text { United States' immigration policies and } \\
\text { the overall receiving context }\end{array}$ \\
\hline $\begin{array}{l}\text { Wave } 3 \\
\text { (cont.) }\end{array}$ & $\begin{array}{l}\text {-Many Colombian activists worldwide called } \\
\text { for peaceful demonstration against the } \\
\text { guerrilla groups, the kidnappings, the violence } \\
\text { in the country, and in favor of the release of } \\
\text { the many other (approximately 700) } \\
\text { Colombians who remained captive. } \\
\text {-Thus, the incidence of kidnapping reportedly } \\
\text { decreased considerably and the dream for } \\
\text { peace in Colombia seemed closer to being a } \\
\text { reality facilitating the return of many } \\
\text { Colombians. }\end{array}$ & $\begin{array}{l}\text {-Given the severe consequences faced by } \\
\text { undocumented immigrants as a result of } \\
\text { "tighter immigration controls and security } \\
\text { issues raised after September 11, 2001" } \\
\text { (Bérubé, 2005, p. 1), the uncertainty of the } \\
\text { immigration laws in the United States and } \\
\text { the hope that the home situation would } \\
\text { improve in Colombia, it can be said that } \\
2008 \text { signified the end of wave } 3 \text { of } \\
\text { Colombian immigration to the United } \\
\text { States. }\end{array}$ \\
\hline \multicolumn{3}{|c|}{$\begin{array}{l}1 \text { (Collier \& Gamarra, 2001; Dix, 1987; Osterling, 1989; Reimers, 2005; Sanchez, 2003); }{ }^{2} \text { (Reimers, 2005); } \\
{ }^{3} \text { (Collier \& Gamarra, 2001; Dix, 1987; Osterling, 1989; Reimers, 2005; Sanchez, 2003); }{ }^{4} \text { (Sanchez, 2003, p. } \\
\text { 58); }{ }^{5} \text { (United States Immigration and Naturalization Services [USINS], 1970); }{ }^{6} \text { (Dix, 1987; Osterling, } \\
\text { 1989; Sanchez, 2003); }{ }^{7} \text { (Osterling, 1989; Sanchez, 2003); }{ }^{8} \text { (Wilson \& Zambrano, 1994); }{ }^{9} \text { (USINS, 1995); } \\
{ }^{10} \text { (Collier \& Gamarra, 2001, Reimers, 2005; Sanchez, 2003; Shifter, 1999); }{ }^{11} \text { (Collier \& Gamarra, 2001; } \\
\text { Reimers, 2005). }\end{array}$} \\
\hline
\end{tabular}

\section{Colombians in the United States: Present Situation}

Statistics from the U.S. Census indicate that there were 471,000 documented Colombian-born immigrants residing in the country in the year 2000 (Guzmán, 2001), however, in 2003 it was estimated that there were approximately 2 million Colombians in the USA (Bérubé, 2005). Per the Migration Policy Institute tabulations from the U.S. Census Bureau's 2011 American Community Survey, there are 658,667 Colombian born residents in the United States (American FactFinder, 2011). Many contend that this is not an accurate count since it does not capture the undocumented who, because of fear of deportation, avoid the census count. Consequently, the exact number of Colombians in the United States is difficult to determine, especially through the U.S. Census (Collier \& Gamarra, 2001; Reimers, 2005; Sanchez, 2003).

The primary states where Colombians live are Florida, New York, and New Jersey. Table 2 shows the states with the largest Colombian population, per the Migration Policy Institute tabulations from the US Census Bureau's 2011 American Community Survey (American FactFinder, 2011). Despite these statistics, available empirical data regarding the reception of Colombians in the United States continue to be limited. 
Table 2 States with the Largest Colombian Population in the United States: 2011

\begin{tabular}{lr}
\hline State & Colombian Population 2011 \\
\hline Florida & 228,619 \\
New York & 97,623 \\
New Jersey & 80,659 \\
California & 35,976 \\
Texas & 35,013 \\
Georgia & 20,591 \\
Massachusetts & 18,417 \\
Connecticut & 12,811 \\
Pennsylvania & 12,224 \\
Illinois & 15,260 \\
North Carolina & 11,283 \\
Virginia & 11,205 \\
Louisiana \& other states & 127,773 \\
\hline Total & 658,667 \\
\hline
\end{tabular}

Data obtained with authorization from Migration Policy Institute, 2011.

There are primarily two studies that address the migration of Colombians to the United States. While Sanchez's (2003) time periods of the waves are historically linked to the domestic circumstances that surrounded their migration, his study focused mostly on the "New York context of reception" (p. 54). Collier and Gamarra (2001), on the other hand, focused on some elements of the immigration of Colombians in South Florida. Their findings were published as a white paper titled "Colombian Diaspora in South Florida” (p. 1).

Sanchez (2003) interviewed numerous community leaders and attended meetings to gather the information he presented in his dissertation. Collier and Gamarra (2001) conducted a research study, together with a team of eight students. Although they did not clearly specify the method they used to collect their data, their report concentrated primarily on the immigration experience of Colombians who arrived during wave 3 . In their study, wave 3 Colombian immigrants reported that the reasons for leaving Colombia included an intricate mix of economic and political factors, but the political factors were dominant. Many economically and politically influential people in Colombia expressed their concern that the exit of these immigrants was causing a brain drain in Colombia and advocated for Colombians to stay in the country. Overall, wave 3 immigrants from the 
upper classes "tend to feel that they have dropped one or more social classes since their arrival in the United States" (Collier \& Gamarra, 2001, p. 9). Other studies (DuquePáramo, 2004; Gonzalez-Eastep, 2007) explored specific issues with Colombians in particular regions in the United States, but they did not address the immigrants' experiences.

\section{Previous Studies on the Well-Being of Immigrants}

The well-being of immigrants has been widely documented on the basis of existing theory and research. Phinney, Horenczyk, Liebind, and Vedder (2001) suggest an "international model for understanding psychological outcomes for immigration [and assertthat the] combination of a strong ethnic identity and a strong national identity promotes the best adaptation" (p. 1). They state that the relationship between the characteristics and attitudes of immigrants, in addition to the response of the host society, are the best determinants of psychological well-being. This relationship is also affected by the status of the particular immigrant group the person belongs to (Phinney et al. 2001).

The psychosocial well-being of immigrants has also been studied by using a framework of acculturation, ethnic identity, and racial identity (Kuo-Jackson, 2000). That author asserts that individuals from a minority culture must deal with four psychosocial issues: (a) conflict between cultures, (b) racism and discrimination, (c) protection of their cultural and ethnic traditions, and (d) facing/confronting their minority status (KuoJackson, 2000).

Other studies have looked at the relationship between acculturation, ethnic identity, and psychological well-being with diverse communities. Abouguendia (2001) studied the acculturative stressors, ethnic identity, and psychological well-being among immigrants and second-generation individuals in the North American population. Psychological wellbeing has also been considered in the realm of specific demographic characteristics and life satisfaction (Christopher \& Aroian, 1998). It has also been documented that ethnic identity positively correlates with well-being, self-esteem, and resilience. Zhou and Bankston (1998) found that high levels of ethnic identity and attachment were linked to behaviors that allow for stronger academic performance and greater motivation. Also, in a meta-analysis conducted by Sam (2000), a moderate but consistent relationship was found between ethnic identity and self-esteem.

Given the review of the theories and empirical studies with regard to the well-being of immigrants, and specifically Colombians in the United States, the importance of understanding immigrant adjustment to the receiving country from different theoretical perspectives has been documented. However, no research was found that studies the psychosocial well-being of immigrants from the acculturation, ethnic identity, resilience, and self-esteem perspective as proposed in this study (figure 1). 


\section{Conceptual Framework Guiding the Present Study}

In this study it was hypothesized that (a) there is a positive relationship between the well-being of the participants and their level of acculturation, self-esteem, resilience, and ethnic identity for all subjects in the sample, (b) there are different predictors of wellbeing for Colombians in the study sample, and (c) there are different predictors of wellbeing for participants in each of the waves. (See Figure 1)

Well-being, the dependent variable on which the influence of the other four factors was sought, is described as the position of being joyful, in good physical shape, or wealthy (Morris, 1981). The World Health Organization (WHO) defines health as "a state of complete physical, mental, and social well-being and not merely the absence of disease or infirmity" (WHO, 1948, p. 100). Psychological well-being includes emotional feelings of pleasure related to the current life experience of the individual (Campbell, 1981; Dupuy, 1977). Furthermore, psychosocial well-being addresses the relationship between conditions in society (i.e., social factors, demographic factors, SES), how healthy individuals can adjust to their environment, and the psychological state of the individual.

Acculturation is defined as the changes that groups and individuals experience when they come into contact with two or more cultures. Acculturation includes the psychological, social, and cultural aspects of the adaptation process and outcome (Williams \& Berry, 1991). Although changes occur in the dominant culture and the minority group, it is usually the non-dominant or minority group that experiences the most change. The minority group often voluntarily accepts or is forced to accept the language, religion, laws, and educational institutions of the host culture. Acculturation reflects the degree of agreement with the norms, values, attitudes, beliefs, and preferences of a particular group to the host society and culture (Berry, 1990; Berry, 1992; Marino, Stuart, \& Minas, 2000).

Ethnic identity is defined as the degree to which the individual understands his or her culture and is self-assured of the choices made about upholding or not upholding the country of origin's customs and values (Phinney, 1998). According to Phinney, each person's attitude toward their own cultural group is essential to their psychological wellbeing; therefore, ethnic identity becomes a basic part of acculturation. Ethnic identity is not a static construct and varies over an individual's life span. Phinney proposes that ethnic identity develops over time as a result of the individual's exploration and decisionmaking process regarding what part they want culture to play in their lives.

Resilience has been defined as the capacity to withstand life stressors, thrive, and make meaning from challenges (Greene, 2012). Cultural resilience refers to the capacity of specific human cultures to endure stressors such as contact with other cultures and disasters, and the ability to uphold critical cultural knowledge all the way through generations, regardless of challenges and complexities. Resilience is also a personal characteristic of an individual who is able to make the required psychosocial adjustments when faced with adversity (Richmind \& Bearslee, 1988; Wagnild \& Young, 1990). 
Figure 1 Framework of well-being of Colombian immigrants in the United States.

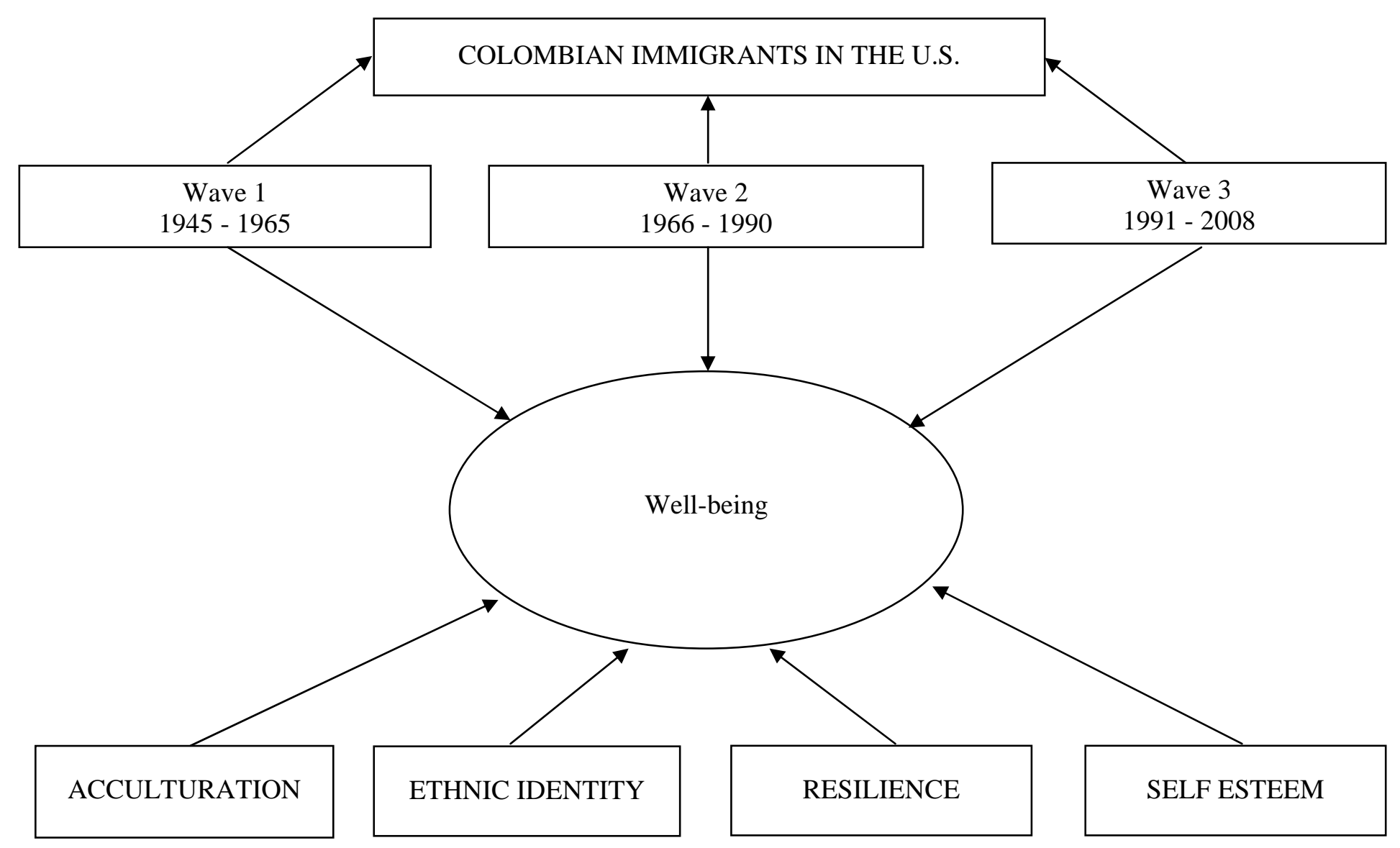


Resilience is an inferred process because it implies that the individual is presently doing fine and that there have been exceptional circumstances that threaten positive outcomes (Masten \& Reed, 2002).

Self-esteem is defined as the ability to form an identity and attach a value to it (McKay \& Fanning, 2000). Self-esteem has also been defined as that aspect of selfconcept that evaluates the self. Hewitt (2002) posits that self-esteem has been entrenched in the psychological ideas of acceptance of the child early in life, receiving positive evaluation from people significant to the person, being compared with others in a favorable way, being compared with the ideal self, and having the ability to take successful action. He argues that self-esteem is a socially constructed emotion that could be called mood, and as such, can be an indicator of well-being.

\section{Method}

\section{Research Design}

This study used an exploratory survey design to examine the extent to which acculturation, ethnic identity, self-esteem, and resilience explain the well-being of Colombian immigrants in the United States across the three waves of immigration (wave 1, from 1945-1964; wave 2, from 1965-1989; and wave 3, from 1990-2008). It was hypothesized that (a) there is a positive relationship between the well-being of the participants and their level of acculturation, self-esteem, resilience, and ethnic identity for all subjects in the sample, (b) there are different predictors of well-being for Colombians in the study sample, and (c) there are different predictors of well-being for participants in each one of the immigration waves.

Because the study of Colombians in the United States is a relatively new area, especially investigating their psychosocial well-being, this exploratory study yielded new insights into the well-being of Colombians in this country. However, because of the specific research design of this study, its results cannot be statistically generalized to the population from which the data were drawn.

\section{Sample and Sampling Technique}

For the purpose of this study, respondents born in Colombia who were 18 years old, or older, at the time of participation, who immigrated to the United States between the years 1945 and 2002, and who were 5 years old, or older, at the time of arrival were eligible to participate. It was stipulated that participants had to have arrived in the country after age 5, since, according to Park (1999), individuals who immigrated to the receiving country before the age of 5 were considered to be part of the second generation of immigrants because of the similarity to the number of years of education and socialization of the people who were actually born in the receiving country. It iwas also considered that those individuals migrated at a time when they had not been fully acculturated into their heritage (Sam, 2000).

To facilitate the collection of the data, research assistants were sought out from California, Pennsylvania, Florida and Texas. These research assistants were chosen for 
their connection to the Colombian community in their respective areas and their desire to assist in collecting the data for this study. Research Assistants were given an oral orientation over the phone and guidelines in writing. The researcher prepared all documents, which were placed in brown envelopes that could be sealed. Each research assistant received the envelopes via mail. Due to the fact that they were not conducting structured interviews, but were only giving the envelopes out to the respondents and picking them up, inter-rater reliability was not considered necessary. A non-probability, snowball sampling technique was used in this study.

\section{Variables and Measurements}

Five scales were used in this investigation to establish instruments appropriate to study Colombians in the United States. A challenge in cross-cultural research is obtaining reliable and valid instruments that are not culturally biased. Despite an extensive literature review, as reported earlier, no validated measures were found that tested all of the specific variables used in this study with Colombians; therefore, well-being, the dependent variable (DV), was tested using the General Well-Being Schedule (GWB), (Taylor, et al., 2003) a schedule used to measure the well-being of a number of different populations. The independent variables and the respective measures were Acculturation (Modified Marino Acculturation Scale for Colombians [Marino et al., 2000]), Ethnic Identity (Multigroup Ethnic Identity Measure [MEIM], Phinney, 1992), Resilience (Resilience Scale [Wagnild \& Young, 1987, 1990]), and Self-Esteem (Rosenberg SelfEsteem Scale [Rosenberg, 1965]).

\section{Statistical Analysis}

The data were entered and analyzed using the Statistical Program for the Social Sciences (SPSS). Descriptive statistics (e.g., $M, S D$, frequencies) were computed and a Pearson product moment correlational matrix was generated for all variables, for all three waves, to determine if level of acculturation, ethnic identity, resilience, self-esteem, and well-being are correlated; and if so, the strength of this correlation and which characteristics are significantly correlated. Also, a multiple regression analysis was conducted to determine what amount of variation in well-being is accounted for by the degrees of acculturation, ethnic identity, resilience, and self-esteem, whether this differs by wave, and if any of these variables are significant predictors of well-being for the studied population.

\section{Study Findings}

\section{Demographic Characteristics}

Two hundred and forty-eight questionnaires as designed for this study were returned to this researcher, that is, $24.8 \%$ of the approximate total number of questionnaires distributed. The geographical distribution of the sample is as follows: 97 (39.1\%) of the respondents resided in Florida, 72 (29\%) in California, 40 (16.1\%) in Pennsylvania and $39(15.7 \%)$ in Texas. The final sample consisted of 30 (12.1\%) participants from wave 1 , 133 (53.6\%) from wave 2, and 85 (34.3\%) from wave 3. Their ages ranged from 19 to 79 
years old. The median age for the participants in the study was 48 years. The range of the participants' ages at the time of entering the United States was from 5.5 to 67 years; the median age being 25, and the mode 18 years. However, due to missing data and participants not responding to some questions because they felt it did not apply to them, many questionnaires could not be used for statistical analysis.

\section{Statistical Findings}

A Pearson's correlation co-efficient was calculated for the relationship between all subjects in the sample, the well-being of the participants, and their level of acculturation, self-esteem, resilience, and ethnic identity. Two positive and significant relationships were found for resilience $(r(106)=0.194, p<0.05)$ and self-esteem $(r(106)=0.397, p$ $<0.01$ ), indicating that resilience and self-esteem are correlated with well-being for all participants in the sample (see table 3).

Table 3 Correlation Between Well-Being and All Independent Variables: All Participants $(N=108)$

\begin{tabular}{llccccc}
\hline & & Well-Being & Resilience & Self-Esteem & Ethnic Identity Acculturation \\
\hline \multirow{2}{*}{ Well-Being } & Pearson Correlation & 1.000 & $0.194^{*}$ & $0.397^{* *}$ & -0.076 & -0.162 \\
& Sig. (2-tailed) & 0.000 & 0.044 & 0.000 & 0.434 & 0.094 \\
\multirow{2}{*}{ Resilience } & Pearson Correlation & $0.194^{*}$ & 1.000 & $0.219^{*}$ & 0.155 & $-0.325^{* *}$ \\
& Sig. (2-tailed) & 0.044 & 0.000 & 0.023 & 0.109 & 0.001 \\
\multirow{2}{*}{ Self-Esteem } & Pearson Correlation & $0.397^{* *}$ & $0.219^{*}$ & 1.000 & $0.269^{* *}$ & -0.106 \\
& Sig. (2-tailed) & 0.000 & 0.023 & 0.000 & 0.005 & 0.276 \\
Ethnic & Pearson Correlation & -0.076 & 0.155 & $0.269^{* *}$ & 1.000 & -0.188 \\
Identity & Sig. (2-tailed) & 0.434 & 0.109 & 0.005 & 0.000 & 0.051 \\
\multirow{2}{*}{ Acculturation } & Pearson Correlation & -0.162 & $-0.325^{* *}$ & -0.106 & -0.188 & 1.000 \\
& Sig. (2-tailed) & 0.094 & 0.001 & 0.276 & 0.051 & 0.000 \\
\hline
\end{tabular}

* Correlation is significant at the 0.05 level (2-tailed).

** Correlation is significant at the 0.01 level (2-tailed).

To determine if any of the independent variables were significant predictors of wellbeing for Colombians in the study sample, a multiple linear regression was performed (see table 4) controlling for all independent variables (resilience, ethnic identity, selfesteem, and acculturation). Regression results $\left(R^{2}=0.225, R^{2} \mathrm{adj}=0.195, F[4,104]=7.493, p\right.$ $<0.05$ ) showed that some of the independent variables in the model are significant predictors. Per the results, it can be concluded that all four independent variables account for $22.5 \%$ of the variance in well-being. The results indicated not only that self-esteem significantly predicts well-being for all Colombians in the study, but also that there is a significant but negative relationship between ethnic identity and well-being. Participants' well-being increased by 1.461 units for each unit increase of self-esteem. Furthermore, 
the results indicated that Colombians' well-being decreases by -.484 for each unit increase of ethnic identity.

Table 4 Multiple Linear Regression-Well-Being (DV) and Acculturation, Self-Esteem, Resilience, Ethnic Identity (IV): All Participants $(N=108)$

\begin{tabular}{|c|c|c|c|c|c|}
\hline \multirow[b]{2}{*}{ Model } & \multicolumn{2}{|c|}{$\begin{array}{l}\text { Unstandardized } \\
\text { Coefficients }\end{array}$} & \multirow{2}{*}{$\begin{array}{c}\text { Standardized } \\
\text { Coefficients } \\
\text { Beta }\end{array}$} & \multirow[b]{2}{*}{$t$} & \multirow[b]{2}{*}{ Sig. } \\
\hline & B & Std. Error & & & \\
\hline (Constant) & 49.635 & 20.354 & --- & 2.439 & 0.016 \\
\hline Acculturation & -0.115 & 0.083 & -0.129 & -1.394 & 0.166 \\
\hline Self-Esteem & 1.461 & 0.315 & 0.424 & 4.632 & 0.000 \\
\hline Resilience & 0.058 & 0.057 & 0.095 & 1.012 & 0.314 \\
\hline Ethnic Identity & -0.484 & 0.193 & -0.229 & -2.507 & 0.014 \\
\hline
\end{tabular}

To determine if there is a significant predictor of well-being for those individuals by wave, a multiple linear regression was performed, controlling for other independent variables (resilience, self-esteem, ethnic identity, and acculturation). Regression results $\left(R^{2}=0.388, R^{2}\right.$ adj=0.304, $\left.F[4,29]=4.596, p<0.05\right)$, indicated that for wave 3, the overall model significantly predicts well-being (see table 5). This model accounts for $38.8 \%$ of the variance in well-being. The results revealed that self-esteem significantly predicts well-being for all Colombians who entered the United States during wave 3. Additionally, there is a significant but negative relationship between ethnic identity and well-being. Per the results, it can be concluded that participants' well-being increased by 1.580 units for each unit increase of self-esteem when all other IVs are held constant. Furthermore, the results indicated that the well-being of Colombians in wave three decreases by -0.907 units for each unit increase of ethnic identity when all other IVs are held constant.

Table 5 Multiple Linear Regression-Well-Being- (DV) and Acculturation, Self-Esteem, Resilience, Ethnic Identity (IV): Wave 3( $N=34)$

\begin{tabular}{|c|c|c|c|c|c|}
\hline \multirow[b]{2}{*}{ Model } & \multicolumn{2}{|c|}{$\begin{array}{l}\text { Unstandardized } \\
\text { Coefficients }\end{array}$} & \multirow{2}{*}{$\begin{array}{c}\begin{array}{c}\text { Standardized } \\
\text { Coefficients }\end{array} \\
\text { Beta }\end{array}$} & \multirow[b]{2}{*}{$t$} & \multirow[b]{2}{*}{ Sig. } \\
\hline & B & Std. Error & & & \\
\hline (Constant) & 45.455 & 44.757 & --- & 1.016 & 0.318 \\
\hline Resilience & 0.125 & 0.097 & 0.246 & 1.282 & 0.210 \\
\hline Self-Esteem & 1.580 & 0.771 & 0.394 & 2.048 & 0.050 \\
\hline Ethnic Identity & -0.907 & 0.315 & -0.486 & -2.883 & 0.007 \\
\hline Acculturation & -0.072 & 0.161 & -0.080 & -0.448 & 0.658 \\
\hline
\end{tabular}


To determine if there are any differences by gender, a multiple linear regression was performed (see table 6) to determine whether any of the four independent variables (resilience, ethnic identity, self-esteem, and acculturation) was a significant predictor of well-being for Colombians, divided by gender. The results $\left(R^{2}=0.377, R^{2}\right.$ adj $=0.316, F[4$, $41]=6.1936, p<0.05$ ) indicated that the overall model significantly predicts well-being for male participants in the study. This model accounts for $37.7 .0 \%$ of the variance in well-being. Per the results, not only does self-esteem significantly predict well-being for all Colombian men in the sample, but also there is a significant but negative relationship between ethnic identity and well-being for male participants. It can be concluded that male participants' well-being increased by 1.687 units for each unit increase of selfesteem when all other IVs were held constant. Furthermore, the results indicated that the well-being of the Colombian men decreases by -0.975 units for each unit increase of ethnic identity when all other IVs are held constant.

Table 6 Multiple Linear Regression*_Well-Being (DV) and Acculturation, Self-Esteem, Resilience, Ethnic Identity (IV): Men ( $N=48)$

\begin{tabular}{|c|c|c|c|c|c|}
\hline \multirow[b]{2}{*}{ Model } & \multicolumn{2}{|c|}{$\begin{array}{l}\text { Unstandardized } \\
\text { Coefficients }\end{array}$} & \multirow{2}{*}{$\begin{array}{c}\text { Standardized } \\
\text { Coefficients } \\
\text { Beta }\end{array}$} & \multirow[b]{2}{*}{$\mathrm{t}$} & \multirow[b]{2}{*}{ Sig. } \\
\hline & B & Std. Error & & & \\
\hline (Constant) & 69.207 & 30.444 & --- & 2.273 & 0.028 \\
\hline Resilience & 0.073 & 0.068 & 0.147 & 1.079 & 0.287 \\
\hline Self-Esteem & 1.687 & 0.476 & 0.489 & 3.546 & 0.001 \\
\hline Ethnic Identity & -0.975 & 0.291 & -0.465 & -3.348 & 0.002 \\
\hline Acculturation & -0.175 & 0.121 & -0.199 & -1.446 & 0.156 \\
\hline
\end{tabular}

This study also looked at the well-being of Colombians who entered the United States as political refugees to determine if the way Colombians entered the country was a predictor of well-being for all participants in the study, and divided by wave. A multiple linear regression was performed. When designating "political refugee" as the referent group, and all others as the base group, regression results $\left(R^{2}=0.319, R^{2}\right.$ adj $=0.283, F[5$, $95]=8.898, p<0.05$ ) indicated that the overall model significantly predicts well-being and accounts for $31.9 \%$ of the variance in well-being (see table 7 ). The results denoted that there is a negative relationship between well-being and having entered as a political refugee, -17.140 units lower than Colombians with other entry statuses.

To determine if there was a significant relationship between well-being and entering as a political refugee by wave, a multiple linear regression was performed controlling for all independent variables. Colombians who entered as political refugees between the years 1966 and 1990 reported a lower level of well-being. Regression results $\left(R^{2}=0.343\right.$, $R^{2}$ adj $0.279, F[5,51]=5.330, p<0.05$ ) indicated that there is a negative relationship between well-being and having entered as a political refugee during wave 2 (see table 8 ). 
Table 7 Multiple Linear Regression-Well-Being (DV) and Acculturation, Self-Esteem, Resilience, Ethnic Identity, Entry Status_Political Refugee (IV): All Participants $(N=101)$

\begin{tabular}{lrrrrr}
\hline & \multicolumn{2}{c}{$\begin{array}{c}\text { Unstandardized } \\
\text { Coefficients }\end{array}$} & $\begin{array}{c}\text { Standardized } \\
\text { Coefficients }\end{array}$ & & \\
\cline { 2 - 5 } Model & B & Std. Error & Beta & \multirow{2}{*}{$t$} & Sig. \\
\hline (Constant) & 45.146 & 19.776 & --- & 2.283 & 0.025 \\
Acculturation & -0.129 & 0.081 & -0.145 & -1.591 & 0.115 \\
Ethnic Identity & -0.452 & 0.196 & -0.208 & -2.302 & 0.024 \\
Self-Esteem & 1.679 & 0.310 & 0.492 & 5.418 & 0.000 \\
Resilience & 0.052 & 0.055 & 0.086 & 0.938 & 0.351 \\
Dummy entry status-PR & -17.140 & 5.353 & -0.275 & -3.202 & 0.002 \\
\hline
\end{tabular}

Table 8 Multiple Linear Regression-Well-Being (DV) and Acculturation, Self-esteem, Resilience, Ethnic Identity, Entry Status- Political Refugee (IV): Wave 2 $(N=57)$

\begin{tabular}{|c|c|c|c|c|c|}
\hline \multirow[b]{2}{*}{ Model } & \multicolumn{2}{|c|}{$\begin{array}{l}\text { Unstandardized } \\
\text { Coefficients }\end{array}$} & \multirow{2}{*}{$\begin{array}{c}\begin{array}{l}\text { Standardized } \\
\text { Coefficients }\end{array} \\
\text { Beta }\end{array}$} & \multirow[b]{2}{*}{$t$} & \multirow[b]{2}{*}{ Sig. } \\
\hline & $\mathrm{B}$ & Std. Error & & & \\
\hline (Constant) & 47.969 & 23.952 & --- & 2.003 & 0.051 \\
\hline Acculturation & -0.167 & 0.101 & -0.199 & -1.664 & 0.102 \\
\hline Ethnic Identity & -0.064 & 0.266 & -0.029 & -0.242 & 0.810 \\
\hline Self-Esteem & 1.427 & 0.382 & 0.455 & 3.736 & 0.000 \\
\hline Resilience & 0.033 & 0.071 & 0.055 & 0.463 & 0.645 \\
\hline Entry status-Political Refugee & -23.483 & 6.787 & -0.402 & -3.460 & 0.001 \\
\hline
\end{tabular}

The overall model accounts for $34.3 \%$ of the variance in well-being. It can be concluded that Colombians who entered the United States as political refugees during wave 2 report a decrease in well-being, -23.483 units lower than Colombians who entered with other statuses.

\section{Discussion}

As stated earlier, this study examined the extent to which acculturation, ethnic identity, self-esteem, and resilience explain the well-being of Colombian immigrants in the United States across the three waves of immigration, that is, wave 1, years 19451964; wave 2, years 1965-1989; and wave 3, years 1990-2008. 
The participants in this study represented a diverse sample of Colombian immigrants in the United States, as evidenced by the demographic characteristics previously presented. The findings show that self-esteem correlated with and was a predictor of well-being. Participants in the sample, both as a group and divided by waves, exhibited high levels of well-being as their level of self-esteem increased. Additionally, significant variance was found in the well-being of Colombians in the study. In previous studies done with Latinos (Gonzalez-Eastep, 2007), self-esteem has had a strong correlation with family functioning (Green \& Way, 2005), ethnic-racial identity (Phinney, 1992), and having good family support and high family functioning (Gonzalez-Eastep 2007); but given the strong association, researchers have wondered if the reported high levels of self-esteem have been a barrier against the effects of other variables, in this case, acculturation, ethnic identity, and resilience.

The results of the present study indicate that ethnic identity negatively predicts wellbeing for all participants in the sample, and for Colombian men who entered the United States during wave 3 specifically; consequently, to the extent that their ethnic identity increased, their well-being decreased. Thus, male participants from wave 3 seem to have a strong identity with the Colombian culture or ethnic group, but this identity seems to create a decrease of well-being.

Studies have found that ethnic identity decreased between first- and secondgeneration immigrants (Buriel, 1987), and that an increase in acculturation to the host culture leads to a decrease of identity with one's own culture. Only first-generation Colombians participated in this study, and their degree of acculturation was not significant. It can be concluded that the men in this study, as first-generation immigrants, did not show a significant degree of acculturation to the mainstream society due to a strong attachment to their ethnic group, which in turn negatively affected their wellbeing. Although a strong ethnic identity can be a safeguard for experiences of racial discrimination (Cross, 1995), it can also be an impediment to well-being.

The finding that ethnic identity has a significant but negative effect on well-being was not expected, but can be explained by exploring feelings of discrimination, marginalization, or exclusion from mainstream society, dissatisfaction outside the country of origin, and cultural uncertainty. As Colombian men feel they belong to their nationality, their ethnic identity is delineated by their subjective personal knowledge about their country, and the pride Colombians feel for being members of that ethnic group. A strong ethnic identity of men in the sample does not seem to be a safeguard for their overall well-being; therefore, it affects them negatively.

In the present study, the well-being of Colombians who entered the United States as political refugees was lower than Colombians with other entry statuses. Given the continued violence in Colombia, these findings are not surprising. This specific study did not ask any other questions regarding the exposure to trauma; therefore there is no other reference to the degree of suffering or the respondents' attempts to seek mental health services. After further analysis, men who entered during wave 2 as political refugees reported a lower level of well-being. Although Colombians have lived amid violence for more than 40 years, the literature points out that it was in the late 1980s (last part of wave 
2) and the 1990s (wave 3) that most Colombians sought to leave the country because of the violence.

\section{Limitations}

This study used a snowball sampling technique; therefore the results may be biased towards one group of respondents with similar characteristics. The questionnaire presented limitations due to its length and did not have an option of "not applicable" which could have helped reduce the large number of missing data. The scales used were developed in the English language and were validated with other ethnic groups. Additionally, the use of triangulation, including one-on-one interviews, would have yielded more in-depth responses and provided richer information about the immigrant trajectory.

\section{Conclusion}

Given the many challenges immigrants face before and after immigration, social workers need to be prepared to serve this population at the individual and macro levels, particularly given the existing stereotypes and polarized views about immigrants and the impact they have on the country.

As the social work profession is challenged to gain a further understanding of diversity, social workers need to be culturally sensitive and competent to work effectively with clients and people from all different backgrounds. Latinos, as a group, share many characteristics, however upon closer examination, those born in South American exhibit great variations according to the country of birth (Migration Policy Institute, 2006). Therefore, it is necessary to examine, treat, and study Latino groups individually, as proposed in the literature (Kouyoumdjian, Zamboanga, \& Hansen, 2003; Portes \& Rumbaut, 1996), and not solely as a collective ethnic group.

A significant contribution of this investigation was the inclusion of variables not previously explored with Colombians in the United States. Additionally, this research was innovative in assessing the factors contributing to the well-being of Colombian immigrants and in the search for scales that are appropriate to study this population. Although the results have to be considered with caution, the study opens doors to future research and the provision of human services for Colombians in the United States.

The findings of this study suggest that in working with Colombians, it is important to keep in mind that their well-being is impacted by their self-esteem and their ethnic identity, especially for Colombian men.

With this in mind, social work educators have the professional responsibility to train social workers to understand an immigrant's pre-departure experiences and the relationship between an immigrant's adjustment and his or her subsequent well-being. Specific to Colombian immigrants, it is important that social workers understand, plan, and implement appropriate services for these clients. For example, many Colombian immigrants suffered the consequences of the undeclared civil war in their country; therefore, they may experience PTSD or other mental illnesses that require special mental 
health programs. Clearly, there is also a need for social workers to be familiar with immigration laws and policies to be able to advocate for immigrants and to assist in policy development and implementation that will address the specific needs of Colombians and other immigrants.

Future research is needed to measure the generational status of Colombians and assess their psychosocial well-being. It would be of great interest to further study the plight of the Colombian political refugees in the United States and what kind of services are available for this population.

\section{References}

Abouguendia, M. (2001). Acculturative stressors, ethnic identity and psychological wellbeing among immigrants and second-generation individuals. Alberta, Canada: University of Alberta.

Acosta, Y. D., \& De la Cruz, G. P. (2011). The Foreign born from Latin America and the Caribbean: 2010 American community survey briefs. Retrieved from: http://www.census.gov/prod/2011pubs/acsbr10-15.pdf

American Fact Finder (2011). Migration policy institute tabulations from the US Census Bureau's 2011 American community survey, Table C05006. Place of birth for the foreign-born population. Retrieved from: http://factfinder2.census.gov/faces/nav/jsf/pages/searchresults.xhtml?refresh=t.

Barry, T. (2008). Inside Bush's billion-dollar immigration gulag. America's policy program. Retrieved June 26, 2008 from: http://www.alternet.org/immigration/89102/

Berry, J. W. (1990). Psychology of acculturation: Understanding individuals moving between cultures. In R. W. Brislin (Ed.), Applied cross cultural psychology (pp. 232253). London, England: Sage.

Berry, J. W. (1992). Acculturation and adaptation in a new society. International Migration, 30(Supp. S1), 69-85.

Bérubé, M. (2005). Colombia: In the crossfire. Country profiles. Washington, DC: Migration Policy Institute. Retrieved from http://www.migrationinformation.org/Profiles/display.cfm?ID=344

Buriel, R. (1987). Ethnic labeling and identity among Mexican Americans. In J. S. Phenney \& M. J. Rotheram (Eds.), Children's ethnic socialization (pp. 134-152). Beverly Hills, CA: Sage.

Campbell, A. (1981). The sense of well-being in America. New York, NY: McGraw-Hill.

Christopher, K. A., \& Aroian, K. (1998). Determinants of psychological well-being in immigrants. Boston, MA: Boston College.

Collier, M. W., \& Gamarra, E. A. (2001). Colombian Diaspora in south Florida: A report of the Colombian Studies Institute's Colombian Diaspora Project. Miami, FL: 
Latin American \& Caribbean Center. Retrieved from http://lasa.international.pitt.edu/Lasa2003/CollierMichael.pdf

Cross, W. E., Jr. (1995). The psychology of Nigrescence: Revising the cross model. In J. G. Ponterotto, J. M. Casas, L. A. Suzuki, \& C. M. Alexander (Eds.), Handbook of multi-cultural counseling (pp. 93-135). Thousand Oaks, CA: Sage.

Dix, R. H. (1987). The politics of Colombia. New York, NY: Praeger.

Dupuy, H. J. (1977). The general well-being schedule. In I. McDowell \& C. Newell (Eds.), Measuring health: A guide to rating scales and questionnaire ( $2^{\text {nd }}$ ed., pp. 206-213). New York, NY: Oxford University Press.

Duque-Páramo, M. C. (2004), Colombian immigrant children in the United States: Representations of food and the process of Creolization. Tampa, FL: University of South Florida.

Gonzalez-Eastep, D. (2007). Family support and help seeking behavior of Colombian immigrants. Boston, MA: Boston College.

Greene, M. L., \& Way, N. (2005). Self-esteem trajectories among ethnic minority adolescents: A growth curve analysis of the patterns and predictors of change. Journal of Research on Adolescence, 15(2), 151-178.

Greene, R. R. (Ed.). (2012). Resiliency: An integrated approached to practice, policy and research ( ${ }^{\text {nd }}$ ed.). Washington, DC: NASW Press.

Guarnizo, L. E., Sanchez, A. I., \& Roach, E. (1999). Mistrust: Colombians in New York City and Los Angeles. Ethnic and Racial Studies, 18(2), 367-396.

Guzmán, B. (2001). The Hispanic population: Census 2000 brief. U.S. Department of Commerce. Economics and Statistics Administration. U.S. Census Bureau. Retrieved from: http://www.census.gov/prod/2001pubs/c2kbr01-3.pdf

Hing, B.O. (2004). Defining America through immigration policy. Philadelphia, PA: Temple University.

Hewitt, J. P. (2002). The social construction of self-esteem. In C. R. Snyder \& S. J. Lopez (Eds.), Handbook of positive psychology (pp. 135-147). New York, NY: Oxford University Press.

InfoPlease. ( 2011). Hispanic Americans: Census facts. Information Please ${ }^{\circledR}$ Database, Pearson Education, Inc. Retrieved from http://www.infoplease.com/spot/hhmcensus1.html\#ixzz2UCRYSioQ

Jones-Correa, M. (1998). The marginalization of the Latino immigrant, between two nations: The political predicament of Latinos in New York City. Ithaca, NY: Cornell University.

Kouyoumdjian, H., Zamboanga, B. L., \& Hansen, D. J. (2003). Barriers to community mental health services for Latinos: Treatment considerations. Clinical Psychology: Science and Practice, 10(4), 394-422. 
Kuo-Jackson, Y. P. (2000). Minority experiences across Asian American ethnic groups and generational levels: Ethnic identity, bicultural stress, perceived prejudices, and racial consciousness. Unpublished doctoral dissertation. Lincoln, NE: University of Nebraska.

Longres, J., \& Patterson, D. (2000). Social work practice with Latino American immigrants. In P. Balgopal (Ed.), Social work practice with immigrants and refugees (pp. 65-126). New York, NY: Columbia University.

Mahoney, A. M. (Ed.). (2004). The health and well-being of Caribbean immigrants in the United States. New York, NY: Haworth Social Work Practice Press.

Marino, R., Stuart, G. W., \& Minas, I. H. (2000). Acculturation of values and behavior: A study of Vietnamese immigrants. Measurement and Evaluation in Counseling and Development, 33(1), 21-41.

Masten, A. S., \& Reed, M. G. J. (2002). Resilience in development. In C. R. Snyder \& S. J. Lopez (Eds.), Handbook of positive psychology (pp.74-88). New York, NY: Oxford University Press.

McKay, M., \& Fanning, P. (2000). Self-esteem ( $3^{\text {rd }}$ ed.). Oakland, CA: New Harbinger Publications.

Morris, W. (Ed.) (1981). American heritage dictionary of the English language. Boston, MA : Houghton Mifflin Co.

Osterling, J. P. (1989). Democracy in Colombia: Clientelist politics and guerrilla warfare. New Brunswick, NJ: Transaction Books.

Park, E. J .W. (1999). Friends or enemies?: Generational politics in the Korean American community. Qualitative Sociology, 22(2), 161-175.

Phinney, J. S. (1992). The multigroup ethnic identity measure: A new scale for use with adolescents and young adults from diverse groups. Journal of Adolescent Research, $7(2), 156-176$.

Phinney, J. S. (1998). Ethnic identity and acculturation. Paper presented at the International Conference on Acculturation, University of San Francisco.

Phinney, J. S. (2003). Ethnic identity and acculturation. In K. M. Chun, P. B. Organista, \& G. Marin (Eds.), Acculturation: Advances in theory, measurement, and applied research (pp. 3-13). Washington, DC: American Psychological Association.

Phinney, J. S., Horenczyk, G., Liebkind, K., \& Vedder, P. (2001). Ethnic identity, immigration, and well-being: An interactional perspective. Journal of Social Issues, 57(3), 493-510.

Portes, A., \& Rumbaut, R. G. (1996). Immigrant America: A portrait (2nd ed.). Berkeley, CA: University of California.

Reimers, D. M. (2005). Other immigrants: The global origins of the American people. New York, NY: New York University. 
Richmind, J., \& Beardslee, W. (1988). Resilience: Research and practical implications for pediatrics. Development and Behavior in Pediatrics, 9(3), 157-163.

Rosenberg, M. (1965). Society and the adolescent self-image. Princeton, NJ: University Press.

Rumbaut, R. G. (1996). Immigrants from Latin America and the Caribbean: A socioeconomic profile. In R. I. Rochin (Ed.), Immigration and ethnic communities: A focus on Latinos (pp. 1-7). East Lansing, MI: Julian Samora Research Institute.

Sam, D. L. (2000). Psychological adaptation of adolescents with immigrant backgrounds. The Journal of Social Psychology, 140(1), 5-25.

Sanchez, A. I. (2003). Colombian immigration to Queens, New York: The transnational re-imagining of urban political space. New York, NY: Columbia University.

Segal, U. (2002). A framework for immigration: Asians in the United States. New York, NY: Columbia University.

Segal, U., Elliott, D., \& Mayadas, N. (Eds.). ( 2010). Immigration worldwide: Policies, practices, and trends. Oxford, England: Oxford University.

Shifter, M. (1999). Colombia on the brink: There goes the neighborhood. Foreign Affairs, 78(4), 14-20.

Taylor, J. E., Poston, W. S., Haddock, C. K., Blackburn, G. L., Heber, D., Heymsfield, S. B., Foreyt, J. P. (2003). Psychometric characteristics of the General Well-Being Schedule (GWB) with African-American women. Quality of Life Research, 12(1), 31-39.

Tazi, Z. (2004). Ecuadorian and Colombian children and families. In F. Rowena (Ed.), Culturally competent practice with immigrant and refugee children and families (pp. 233-252). New York, NY: Guilford.

United States Census Bureau (2012). The Foreign-Born Population in the United States: 2010. American Community Survey Reports. Retrieved from: http://www.census.gov/prod/2012pubs/acs-19.pdf

United States Immigration and Naturalization Service (USINS). (1970, 1995). Statistical yearbook of the Immigration and Naturalization Service. Washington, DC: U.S. Government Printing Office.

United States Department of Homeland Security. (2012). Yearbook of immigration statistics: 2011. Washington, DC: U.S. Department of Homeland Security, Office of Immigration Statistics, 2012. Retrieved on 10-5-12 from: http://www.dhs.gov/sites/default/files/publications/immigrationstatistics/yearbook/2011/ois_yb_2011.pdf

Wagnild, G. M., \& Young, H. M. (1987). Resiliency scale. Worden, MT: The Resilience Center. 
Wagnild, G. M., \& Young, H. M. (1990). Resilience among older women. The Journal of Nursing Scholarship, 22(4), 252-255.

Weinstein, J., \& Pillai, V. K. (2001). Demography: The science of population. Boston, MA: Allyn \& Bacon.

Williams, C. L., \& Berry, J. W. (1991). Primary prevention of acculturative stress among refugees: Application of psychological theory and practice. American Psychologist, 46(6), 632-641.

Wilson, S., \& Zambrano, M. (1994). Cocaine, commodity chains, and drug politics: A transnational approach. In G. Gereffi \& M. Korzeniewicz (Eds.), Commodity chains and global capitalism (pp. 297-315). Westport, CT: Greenwood.

World Health Organization (WHO). (1948). Preamble to the Constitution of the World Health Organization as adopted by the International Health Conference, New York, 19-22 June, 1946; signed on 22 July 1946 by the representatives of 61 States (Official Records of the World Health Organization, no. 2, p. 100) and entered into force on 7 April 1948: Author. Retrieved from: http://www.who.int/about/definition/en/print.html

Zhou, M., \& Bankston, C. L. (1998). Growing up American: The adaptation of Vietnamese children in American society. New York, NY: Russell Sage Foundation.

\section{Author note:}

Address correspondence to: Cándida Madrigal, Ph.D., Assistant Professor, Department of Social Work, San Francisco State University, 1600 Holloway Ave., San Francisco, CA 94132. Email: candymadrigal@yahoo.com 